\title{
The Effect of Realia Strategy and Self-Regulated Learning (SRL) to The English Learning Result
}

\author{
Nuke Lismarini, Mustaji, Djoko Adi Walujo \\ The Instructional Technology Program Magister Degree Program \\ PGRI Adibuana University Surabaya
}

\section{Edcomtech}

Jurnal Kajian

Teknologi Pendidikan

Volume 4, No 1, April 2019

49-55

Submitted 03-19-2019

Accepted 05-13-2019

Corresponding Author

Nuke Lismarini

nukelismarini@gmail.com

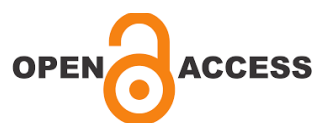

\begin{abstract}
The focus of this study was to determine whether any interactions between Realia Strategy and Self-Regulated Learning (SRL) to the English learning result of the seventh grade students in SMPN 1 \& 2 Dlanggu Mojokerto. The research approach used in this study was a quantitative. The research population was the seventh grade students in SMPN 1 \& 2 Dlanggu Mojokerto. The number of the respondents who took part in this research was 128 . The findings revealed that the majority of the respondents were the seventh grade students and both genders were almost equally represented in the sample. Test and questionnaire were conducted with 128 respondents using a prepared structured test and questionnaire schedule. The test and questionnaire was managed for easy analysis and analysed using SPSS computer program. Based on the data analysis and hypothesis verification, it can be concluded that there are any differences of the English learning result between a group of students who is given a treatment using Realia Strategy and a group of students who is given a treatment using Display Strategy, between a group of students who has High Self-Regulated Learning (SRL) and Low Self-Regulated Learning (SRL), and there are any interactions between Realia Strategy and Self-Regulated Learning (SRL) to the English learning result of the seventh grade students in SMPN 1 \& 2 Dlanggu Mojokerto. It can be said that there is significant interaction of Realia Strategy and Self-Regulated Learning (SRL) to the English Learning Result of the Seventh Grade Students in SMPN 1\& 2 Dlanggu Mojokerto. According to the findings of the research, Realia strategy and Self-Regulated Learning (SRL) are able to be implemented in classroom to improve students' English learning result.
\end{abstract}

Keywords: Realia strategy, Self-Regulated Learning (SRL) 


\section{INTRODUCTION}

In Indonesia, government set English as the main object at school. It is taught and learnt from Elementary School until University. The objective of teaching English is students are intended to have ability in Listening, Speaking, Reading, and Writing. Teaching English is no easy feat. With a variety of different language skill levels in every classroom, teachers must employ effective strategies that allow each student to learn the material. A strategy describes how the ends (goals) will be achieved by the means (Fredman, L, 2015).

The theories explained that media are generally defined as the means by which information is conveyed from one place to another. According to Van Els et al. (1984), media are all aids which may be used by teachers and learners to attain certain educational objectives. Media which carry message stimulate cognitive, feeling, and encourage students to have Self-Regulated Learning (SRL) which are very important to support English learning process. Nowadays, there are many kinds of media to help learning process. The things around us can be used as media such as real object or Realia for teaching and learning.

Realia are objects from real life that often found in our environment and will be used to connect learners with the key focal point of a lesson by allowing multidimensional connection between learned material and the object of the lesson.

Based on the problem and statement of some theories above, a present researcher is curious about The Effect of Realia Strategy and Self-Regulated Learning (SRL) to the English Learning Result.

\section{THEORETICAL REVIEW}

Realia was first used in the late of $19^{\text {th }}$ century and is still mostly used in the classroom by teachers, especially foreign language teachers (Merriam-Webster, 2013). Realia is a term for real things-concrete objects that are used in language classroom to build background knowledge and vocabulary. In order to provide learners experiences during learning, it is aimed to include sensory abilities into learning through realia because students can smell, hear, see, touch, and taste the real objects to boost perception of new topic. Krashen \& Terrel (1995) point out that teacher should help students build confidence to get involved in the class activities and get positive attitudes toward a foreign language. Using realia is one of the most appealing alternatives that enable the learning process more comprehensible, enjoyable, or long running

Like other media, displays can be used to inform, instruct, and persuade the audience. Displays are composed of related materials contain models, captions, printed materials. Displays can be used for both large and small groups. However for large groups, it is important that captions and visuals can be seen at a distance (Lamb, 1996:280).

Display is one of the teaching resources. There are huge number of display resources including printable labels, charts, pictures, handwriting paper. Displays are essential tools for supporting students learning (Anderson, 2011).

Self-Regulated Learning is a sequenced series of practices that virtually any learner can understand and develop. It does not require any particular level of ability or intelligence (Schraw, 1998; Schraw \& Dennison, 1994; Zimmerman \& Schunk, 1998; as cited in Nilson, 2013). Self-Regulated Learning is total-engagement activity involving multiple parts of the brain. It encompasses full attention and concentration, self-awareness and introspection, honest self-assessment, openness to change, genuine self-discipline, and acceptance of responsibility for one's learning (Pintrich, 2000; Zimmerman, 2001, 2002; Zimmerman \& Schunk, 2001 as cited in Nilson, 2013). Self-Regulated Learning is an active and constructive process in which learners primarily set their goals and they try to monitor, regulate and control their cognition, their motives and their behaviors guided by their goals and the structural characteristics of environment (Pintrich, 2000). Furthermore Zimmerman (2008) explained that Self- 
Regulated Learning is the process by which students plan, monitor and regulate their own learning. It refers to thoughts, feelings and actions that are planned and adjusted to improve motivation and learning

Self-Regulated Learning refers to one's ability to understand and control one's learning environment. Self regulation abilities include goal setting, self-monitoring, selfinstruction, and self-reinforcement (Harris \& Graham, 1999; Schraw, Crippen, \& Hartley, 2006; Shunk, 1996). Effective learners are self regulating, analyzing task requirements, setting productive goals, and selecting, adapting or inventing strategies to achieve their objectives. These learners also monitor progress as they work through the task, managing intrusive emotions and waning motivation as well as adjusting strategies processed to foster success. These are the students who ask questions, take notes, and allocate their time and their resources in ways that help them to be in charge of their own learning (Paris \& Paris, 2001). Motivation is an essential variable of Self-Regulated Learning. Students will only employ learning strategies, if they are motivated to do so (Zimmerman, 1989, 2008).

Student learning outcomes are statements that specify what students will know, be able to do or be able to demonstrate when they have completed or participated in a program/activity/ course/ project. Outcomes are usually expressed as knowledge, skills, attitudes or values (Mueller, 2009). The assessment concerns with three main abilities such as knowledge, skill, and attitude which have been formulated to learning result in detail (Mustaji, 2016).

Scroggins (2004) stated that whatever the teachers do to implement student learning outcomes, this initiative must be seen to add value to the teaching and learning process. Value that clearly overweighs the task of constructing student learning outcomes. Those teachers who have taught for years consider that we already measure student learning. However, student learning outcomes really do have a new and useful emphasis that can be best captured by one word "Results" which are collecting, sharing, using them to improve learning. As the teachers teach each lesson and grade the related student assignments, the teachers typically have a clear concept of result expected, and the teachers have defined methods for assessing student work and assigning grades.

The characteristics of a subject is the subject aspects which are able to give a very useful basic in describing a learning strategy (Degeng, 2013). In the subject of English, the basic skills for after year 7 are that the students shall be able to master a vocabulary that covers everyday situations, use basic rules and patterns.

\section{RESEARCH METHOD Research Design}

The design of this study is based on quantitative method. This approach permits to acquire specific and adequate results about The Effect of Realia Strategy and SelfRegulated Learning (SRL) to the English Learning Result of the Seventh Grade Students in SMPN 1 \& 2 Dlanggu Mojokerto.

This study uses the quantitative method in order to collect precise information about the effect of realia strategy, the researcher will observe, interview, and hold a test to the seventh grade students in SMPN 1 \& 2 Dlanggu Mojokerto.

The design of the study is factorial experimental research $(2 \times 2)$, a factorial experiment is an experiment whose design consists of two or more factors. While factorial design is a research design that allows two or more independent variables to be combined in the same study so that the influence of each variable can be evaluated independently of the influences of the others. In addition, a factorial design allows the researcher to determine whether there is an interaction between the independent variables. That is whether the influence of one depend on the specific level of the other variable with which it is combined. To produce a factorial design, each level of one variable is paired with each level of the other independent variables. The design of this study is described as the following table. 
Table 1. Experimental factorial $2 \times 2$ design

\begin{tabular}{lll}
\hline SRL $\$ Strategy & Realia & Display \\
\hline High SRL & Re/HSRL & Di/HSRL \\
\hline Low SRL & Re/LSRL & Di/LSRL
\end{tabular}

The above design describes the differences between the application of Realia strategy for highly Self-Regulated Learning students and Low Self-Regulated Learning students. And also the application of Display strategy for highly Self-Regulated Learning students and Low Self-Regulated Learning students.

\section{Data Collecting Method}

The following techniques will applied during the process of this study i.e. questionnaire and test.

Questionnaire is a research instrument consisting of a series of questions for the purpose of gathering information from respondents. There is a little guidance on the right questions to use. The guideline of a questionnaire that will be discussed are as follows: goal setting and planning, enacting of strategies, task definition, and adaptations based on evaluations of progress (Kristiyati, 2016). There are Self Regulated Learning Strategies for Students i.e. goal setting, planning, self motivation, attention control, flexible use of strategies, self monitoring, help seeking and self-evaluation (Zumbrunn Sharon: 2011). Meanwhile Wolters, 2011 stated that there are three aspects of Self Regulated Learning i.e. Cognitive regulation (rehearsal, elaboration, organization), Motivation (mastery self-talk, relative ability self-talk, relevance enhancement, situational interest enhancement, self-consequating, environment structuring), and Self Regulatory (effort regulation, time/study environment, help-seeking).

Table 2. Aspects of questionnaire scoring

\begin{tabular}{clc}
\hline No & \multicolumn{1}{c}{ Aspects of Scoring } & Score \\
\hline 1 & Rehearsel & $0-5$ \\
\hline 2 & Elaboration & $0-5$ \\
\hline 3 & Organization & $0-5$ \\
\hline 4 & Self-consequating & $0-5$ \\
\hline 5 & Environment structuring & $0-5$ \\
\hline
\end{tabular}

\begin{tabular}{clc}
\hline 6 & Mastery self-talk & $0-5$ \\
\hline 7 & Relative ability self-talk & $0-5$ \\
\hline 8 & Help-seeking & $0-5$ \\
\hline 9 & Performance or extrinsic self-talk & $0-5$ \\
\hline 10 & Time/study environment & $0-5$ \\
\hline & Maximun Score & 50 \\
\hline
\end{tabular}

Test is a series of questions or other instrument used to reinforce learning and to assess students performance in the target language. For spoken test, the student will present their dialogue which expresses asking and giving information about people that has been discussed. The scoring guide used for the spoken test will be described in the following table:

Table 3. Aspects of Speaking Test scoring

\begin{tabular}{rrrr}
\hline No. & \multicolumn{1}{c}{ Aspects of Scoring } & Score \\
\hline 1. & Accuracy & & \\
& - & Logical Sequence of \\
& speaking & $0-5$ \\
& & \\
& & & \\
& & &
\end{tabular}

2. Fluency

$\begin{array}{ll}\text { - Pronunciation } & \\ \text { - Intonation } & 0-5\end{array}$

3. Performance

\begin{tabular}{llc}
$-\quad$ Way of speaking & \\
$-\quad$ Way of expressing & $0-5$ \\
\hline Maximum Score & & 15 \\
\hline
\end{tabular}

While for written test, the total number is 10 items. Dealing with the test scoring, each item is scored 4 points. The result of the test will be formulated as follows:

The result of the test given will show that realia strategy will be considered as one of good strategy in teaching English. From the students learning result is possible to compare the influence of realia strategy and display strategy.

\section{Data Analysis Method}

Data analysis method is a way to analyze the obtained data. In this research, the primary data will be obtained in the form of students' learning result. This means both the experimental and the control groups will be compared one another to know whether 
or not there will be any significant effect between them after treatment.

As it is already described in design research, this research used design factorial $2 \times 2$ and considering the hypothesis, therefore in analyzing data, the researcher will apply ANOVA. The data will be analyzed by using descriptive statistical analysis technique and the hypothesis uses t-test. To ease the whole analysis process, and to make the results of the data analysis is more valid, SPSS windows Version 24 is used. Hypothesis test will show The effect of Realia Strategy and Self-Regulated Learning (SRL) to the English Learning Result of the Seventh Grade Students in SMPN 1 \& 2 Dlanggu Mojokerto.

\section{DISCUSSION}

\section{The Differences of English Learning Result between Realia and Display Strategy}

The first point of this study was determine whether there are any differences of the English learning result between a group of students who is given a treatment using Realia Strategy and a group of students who is given a treatment using Display Strategy to the seventh grade students of SMPN $1 \& 2$ Dlanggu Mojokerto.

Based on the data analysed, the group means are statistically significantly different because the value in the sig.( 2 tailed) row is less than 0.05 . The interpretation of independent sample t-test by looking at the group statistics table, it shows that those students who did not get realia strategy had lower English result than those who got realia strategy.

The sig. (2-tailed) value in the table is 0.001 . This value is less than 0.05 . It can conclude that there is a statistically significant difference between the mean number of English result using Realia strategy and Display strategy.

A number of similar researches conducted may be cited to explain further the effects of Realia Strategy. The Results obtained showed that both realia and models had significant effects on physics students' academic performance using expository teaching approach (Stephen, 2016). According to Bably \& Nusrat (2017), the use of realia is commonplace in the ESL/EFL classroom and is widely considered to have great value in fostering an active teaching-learning environment.

\section{The Differences of English Learning Result between High and Low Self- Regulated Learning}

The second point of this study was determine whether there are any differences of English learning result between a group of students who has High Self-Regulated Learning (SRL) and Low Self-Regulated Learning (SRL) of the seventh grade students in SMPN 1 \& 2 Dlanggu Mojokerto.

In total number of Self-Regulated Learning (SRL) questionnaire were given to the students who learning English in the selected school, students were personally asked to do some tasks within $\mathbf{4 0}$ minutes. It is shown with the previous table.

The figure shows that the group means are statistically significantly different because the value in the sig. (2 tailed) row is less than 0.05 . The interpreation of independent sample ttest by looking at the group statistics table, it shows that those students who did not get realia strategy had lower Self-Regulated Learning (SRL) than those who got realia strategy.

The sig. (2-tailed) value in the table is 0.000 . This value is less than 0.05 . It can conclude that there is a statistically significant difference between the mean number of SelfRegulated Learning (SRL) using Realia strategy and Display strategy.

A number of similar researches conducted may be cited to explain further the effects of Self-Regulated Learning (SRL). Significant relationship between $S R L$ and academic achievement was found (Ibrahim, 2015). Overall, for Hallberg (2017), the relation between SRL and completed thesis was not as strong as expected.

\section{The Interaction between Realia Strategy and Self-Regulated Learning (SRL) to the English Learning Result}

This data analysis and interpretation with reference to the literature review. The aim of this study is to find out whether any 
interactions between Realia Strategy and Display Strategy to the English result and SelfRegulated Learning (SRL) of the seventh grade students in SMPN 1 \& 2 Dlanggu Mojokerto.

As the researcher could collect 128 questionnaires and tests, the figure is adequate to make conclusions. It is shown with the previous table.

The adjusted $r$ square of this model is .453 . $r$ square $=0.496$ means that there is $49.6 \%$ of the correlation in the data. This shows the strong influence. The contribution simultanly of the Realia strategy and Self Regulated Learning to English result is 49.6.

Based on the model summary table, it shows statistically significant probability value (sig.F change) $=.000$. Because sig.F change value is $0.000<0.05$, so $\mathrm{HO}$ is rejected and $\mathrm{Ha}$ is accepted. It means the Realia strategy ang Self -Regulated Learning (SRL) has significant correlation to English result in SMPN 1 \& 2 Dlanggu Mojokerto.

\section{CONCLUSION AND RECOMMENDATION Conclusion}

Based on the data analysis and hypothesis verification, it can be concluded that:

1. There are any differences of the English learning result between a group of students who is given a treatment using Realia Strategy and a group of students who is given a treatment using Display Strategy.

2. There are any differences of the English learning result between a group of students who has High Self-Regulated Learning (SRL) and Low Self-Regulated Learning (SRL).

3. There are any interactions between Realia Strategy and Self-Regulated Learning (SRL) to the English learning result of the seventh grade students in SMPN 1 \& 2 Dlanggu Mojokerto.

It can be said that there is significant effect of Realia Strategy and Self-Regulated Learning (SRL) to the English Learning Result of the Seventh Grade Students in SMPN 1\& 2 Dlanggu Mojokerto.

According to the findings of the research, Realia strategy and Self-Regulated Learning (SRL) are able to be implemented in classroom to improve students' English learning result.

\section{Recommendation}

Based on the result of this research, the following are recommended such as: First, to apply Realia strategy as the instructional material in teaching English. It will encourage the teachers and the students to be drawn to this Realia strategy in teaching learning English to adapt it as an effective strategy that will especially benefit to the students. Second, to encourage Self-Regulated Learning (SRL) in the classroom and structuring feedback to support Self-Regulated Learning (SRL). Third, to improve students abilities in learning English, develop higher English learning result, increase students' English skills to meet learning strategy, enhance students SelfRegulated Learning, good encouragement and the level of interaction that was engendered between Realia Strategy and Self-Regulated Learning (SRL) to the English learning result.

\section{REFERENCES}

Bably, T., \& Nusrat, D. (2017). Using Realia as an Effective Pedagogical Tool. IOSR Journal of Humanities and Social Science (IOSR_JHSS), 22 (11); 01-07

Degeng, Nyoman, S. (2013). Ilmu Pembelajaran: Klasifikasi Variabel untuk Pengembangan Teori dan Penelitian. Bandung: Aras Media

Freedman,L. (2015). Strategy. Oxford: Oxford University Press

Hallberg, David. (2017). Self-Regulated Learning in Students' Thesis Writing. International Journal of Teaching \& EducationV(1), 13-24

Harris, K., \& Graham, S. (1999). Programmatic Intervention Research: Illustrations from the Evolution of Self-Regulated Strategy Development. Learning Disability Quarterl. 22, 251-262

Ibrahim, Esam Eltigani M. (2015). Interaction with the Qur'an and Self-Regulated Learning Vis-a-Vis Academic Achievement of Undegraduate Students. International Journal of Current Research and Academic Review 3(1), 187-197

Mueller, Kate. (2009). A Guide to Developing Measurable Student Learning Outcomes. Canada: Canada College 
Mustaji. (2016). Media Pembelajaran. Surabaya: UNESA University Press

Nilson, Linda B. (2013). Creating SelfRegulated Learners: Strategies to Strengthen Students' Self-Awareness and Learning Skills. Virginia: Stylus Publishing LLC

Paris, S. \& Paris, A. (2001). Classroom Applications of Research on SelfRegulated Learning. Educational Psychology, 36, 89-101

Pintrich, P.R. (2000). The Role of Goal Orientation in Self-Regulated Learning. In M. Boekaerts, P.R. Pintrinch, M. Zeidner (eds). Handbook of Self SelfRegulation. San Diego: Academic Press

Schraw, G., Crippen, K., \& Hartley. (2006). Promoting Self-Regulation in Science Education: Meta cognition as Part of a Broader Perspective on Learning. Research in Science Education, 36, 111139

Scroggins, Bill. (2004). The Teaching-Learning Cycle: Using Student Learning Outcome
Results to Improve Teaching and Learning. California: Modestro Junior College

Shunk, D. (1996). Goal and Self-Evaluative Influences During Children's Cognitive Skill Learning. American Educational Research Journal, 33, 359-382

Stephen, Utibe Abasi S. (2016). Effects of Realia and Models Instructional Materials on Academic Performance in Physics among Senior Secondary School Students in Akwa Ibom State, Nigeria. International Journal of Educatonal Benchmark (IJEB), 3 (1); 45-53

Zimmerman, B. J. (1989). A Social Cognitive View of Self-Regulated Academic Learning. Journal of Educational Psychology, 81(3), 329-339

Zimmerman, B. J. (2008). Investigating Self-Regulation and Motivation: Historical Background, Methodological Developments, and Future Prospects. American Educational Research Journal, 45(1), 166-183 